\title{
Partial substitution of sodium chloride in Toscana sausages and the effect on product characteristics
}

\section{Substituição parcial de cloreto de sódio em linguiça Toscana e os efeitos nas características do produto}

\author{
Diogo Seganfredo ${ }^{1}$; Sidnei Rodrigues ${ }^{1}$; Daneysa Lahis Kalschne ${ }^{2}$; \\ Cleonice Mendes Pereira Sarmento ${ }^{3}$, Cristiane Canan ${ }^{3 *}$
}

\begin{abstract}
High sodium intake has been linked with problems of hypertension and in Brazil, it still has above that recommended by the World Health Organization. Meat products contribute $20-30 \%$ of sodium intake in the diet, indicating the necessity of reducing the amount of sodium added. The aim of this study was to reduce the sodium content in Toscana sausages by partial replacement of sodium chloride with PuraQ Arome NA4 substitute, and to evaluate the effect on physico-chemical and microbiological parameters and sensory acceptability. Three formulations - one control (T1), and one with $20 \%$ (T2) and another with 30\% (T3) sodium reduction compared with the control - were produced. For comparative purposes, the physico-chemical, microbiological and sensory parameters were determined. In the proposed formulations with $20 \%$ and $30 \%$ reduction, the sodium contents were $857.3 \mathrm{mg} 100 \mathrm{~g}^{-1}$

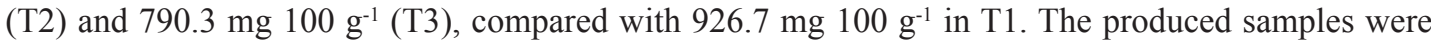
in accordance with the physico-chemical (moisture, lipid, protein and calcium) and microbiological (Salmonella, coagulase-positive Staphylococcus, and sulphite-reducing Clostridium and Coliforms at $45^{\circ} \mathrm{C}$ ) parameters stipulated by Brazilian law. The analysis of lightness and hue indicated that the sample T3 had a more intense red colour, while T1 had a less intense red colour. In the shear force evaluation, no difference was observed between the samples. The sample T2 was the most preferred in the ordering of preference test; however, in the hedonic scale, there was no difference between the means of sensory values for roast colour, aroma, texture, flavour and overall impression, indicating that all samples had adequate sensory acceptance. Acceptability levels were greater than $74.6 \%$ for all attributes evaluated in T1, T2 and T3.
\end{abstract}

Key words: Fresh sausage. Ordering of preference. Sensory acceptance. Sodium reduction. Sodium substitute.

\section{Resumo}

O consumo elevado de sódio tem sido relacionado com problemas de hipertensão arterial e, no Brasil, ainda tem-se um consumo acima do recomendado pela Organização Mundial da Saúde. Os produtos cárneos têm contribuído com 20 a 30\% do sódio ingerido na dieta, indicando a necessidade de redução no sódio adicionado. O objetivo do presente estudo foi reduzir o teor de sódio em linguiça Toscana por meio da substituição parcial do cloreto de sódio $(\mathrm{NaCl})$ pelo substituto PuraQ Arome NA4 e avaliar

\footnotetext{
${ }^{1}$ Discentes, Curso Superior de Tecnologia em Alimentos, Universidade Tecnológica Federal do Paraná, UTFPR, Câmpus Medianeira, PR, Brasil. E-mail: d_seganfredo@yahoo.com.br; srodrigues2012@gmail.com

2 Discente, Programa de Pós-Graduação em Tecnologia de Alimentos, PPGTA, UTFPR, Câmpus Medianeira, PR, Brasil. E-mail: daneysa@yahoo.com.br

3 Profs., Programa de Pós-Graduação em Tecnologia de Alimentos, PPGTA, UTFPR, Câmpus Medianeira, PR, Brasil. E-mail: cleosarmento@utfpr.edu.br; canan@utfpr.edu.br

* Author for correspondence
} 
o efeito deste aditivo na aceitação sensorial da linguiça Toscana. Foram elaboradas três formulações, uma controle (T1), uma com $20 \%$ (T2) e outra com 30\% (T3) de redução de sódio, em comparação à primeira (T1). Para efeitos comparativos, os parâmetros físico-químicos, microbiológicos e sensoriais foram determinados. Nas formulações com proposta de $20 \%$ e $30 \%$ de redução, o teor de sódio foi 857,3 mg $100 \mathrm{~g}^{-1}$ (T2) e 790,3 mg $100 \mathrm{~g}^{-1}$ (T3), comparados com 926,7 mg $100 \mathrm{~g}^{-1} \mathrm{em} \mathrm{T1}$. As formulações elaboradas atenderam os critérios físico-químicos (umidade, lipídio, proteína e cálcio) e microbiológicos (Salmonella, Staphylococcus coagulase positiva, Clostridium sulfito redutor e Coliformes a $45^{\circ} \mathrm{C}$ ) estipulados na legislação brasileira. A análise dos parâmetros luminosidade e tonalidade cromática indicaram que a amostra T3 foi a de cor vermelha mais intensa, enquanto T1 a de cor vermelha menos intensa. Na avaliação da força de cisalhamento, não foi verificada diferença entre as amostras. A amostra T2 foi a mais preferida no teste de ordenação da preferencia, entretanto na escala hedônica não houve diferença entre os valores sensoriais médios para a cor assada, aroma, textura, sabor e impressão global, indicando que todas as amostras foram sensorialmente aceitas. Os índices de aceitabilidade foram superiores a 74,6\% para todos os atributos avaliados em T1, T2 e T3.

Palavras-chave: Linguiça frescal. Ordenação da preferência. Aceitação sensorial. Redução de sódio. Substituto de sódio.

\section{Introduction}

Pork sausages are the oldest meat processed products and are enjoyed by millions of consumers worldwide (WENJIAO et al., 2014). Pork fresh sausages alone, in Brazil in 2011, represented 32.8\% of pork meat purchases (ABIPECS, 2012). Toscana sausages are defined as a raw and cured product that is composed exclusively of pork meat, pork fat and ingredients (BRASIL, 2000), and is one of the main sausages prepared with this meat.

Meat products are an important source of sodium in the human diet, representing $20 \%$ to $30 \%$ of the daily intake (WIRTH, 1991; HENDERSON et al., 2003). In sausages, additions exceeding $2 \mathrm{~g}$ sodium chloride $(\mathrm{NaCl})$ per $100 \mathrm{~g}^{-1}$ of sausage are used (JIMÉNEZ-COLMENERO et al., 2001). Bernardi and Roman (2011a) reported sodium levels of between 1100 and $2657 \mathrm{mg} 100 \mathrm{~g}^{-1}$ in Toscana sausages.

In Brazil, the daily average sodium intake is $4.1 \mathrm{~g}$ sodium per person (SARNO et al., 2013), which is higher than the maximum level of $2 \mathrm{~g}$ sodium (equivalent $5 \mathrm{~g} \mathrm{NaCl}$ ) per person that is recommended by the World Health Organization (WHO) (WHO, 2012). These data are worrisome, considering that high sodium intake is associated with increased blood pressure (ZHAO et al., 2011; WHO, 2012), stroke, left ventricular hypertrophy and kidney disease (HE; MACGREGOR, 2010).
$\mathrm{NaCl}$ is an important ingredient in meat processing because it increases flavour and texture, and it contributes to the extraction of myofibrillar proteins, thus increasing the water retention capability, gel and emulsion formation, and osmotic pressure, and inhibiting microbial growth, thus avoiding deterioration of the meat product (STRASBURG et al., 2010), and therefore cannot be eliminated completely. However, intake in the diet must be reduced, and for this purpose several ingredients have emerged that keep the saltiness characteristics of $\mathrm{NaCl}$, called sodium substitutes. $\mathrm{The} \mathrm{NaCl}$ is largely replaced by potassium chloride $(\mathrm{KCl})$. However, the addition of $\mathrm{KCl}$ in certain amounts may cause undesirable sensory changes, such as a metallic or bitter taste and astringency (GOU et al., 1996; DESMOND, 2006; MA et al., 2013).

Besides the $\mathrm{KCl}$, other ingredients such as $\mathrm{CaCl}_{2}$ (MA et al., 2013; SANTOS et al., 2015), phosphates (RUUSUNEN; PUOLANNE, 2005), transglutaminases (TSENG et al., 2000) and lactate (GOU et al., 1996) have been reported.

Recently, a sodium substitute called PuraQ Arome NA4 (Corbion-Purac) was released, which consists of sugars, salts of organic acids and aromas obtained from the controlled fermentation of sugarcane. The PuraQ Arome NA4 is considered a natural flavour that is able to mimic the taste of meat 
and to control the water activity, which reduces the rate of microbial growth (WILSON et al., 2012).

Considering the high consumption of meat sausages, studies of sodium-content reduction are important to improve the quality of the population's diet (CARRARO et al., 2012). However, $\mathrm{NaCl}$ is an essential ingredient in the meat industry, and a reduction in the content cannot occur without a detailed evaluation of the effects on sensory acceptance and microbiological stability. The aim of this work was to reduce the sodium content in Toscana sausages through partial substitution of $\mathrm{NaCl}$ with PuraQ Arome NA4, and to evaluate the physico-chemical, microbiological and sensory qualities of the elaborated formulations.

\section{Materials and Methods}

The Toscana sausage formulations (Table 1) were prepared in a slaughterhouse located in the West of Paraná. In preparing the curing salt, $\mathrm{NaCl}$, condiment, cochineal carmine and PuraQ Arome NA4 were added to water. The pork meat and fat were ground into $10 \mathrm{~mm}$ discs and added to the brine, and mixed for $3 \mathrm{~min}$. The emulsifier and sodium erythorbate were added to the dough and mixed for $3 \mathrm{~min}$. The final dough temperature was $6 \pm 1{ }^{\circ} \mathrm{C}$, and remained curing for $6 \mathrm{~h}$ in a cold room at $8 \pm 1{ }^{\circ} \mathrm{C}$. The sausages were embedded in natural pork casings of 30-34 mm diameter, and packaged in sealed polyethylene packages of 1 $\mathrm{kg}$. The packages went into the freezing tunnel to reach $-18^{\circ} \mathrm{C}$ internally, and then were placed in cold storage at $-18^{\circ} \mathrm{C}$ until analysis.

Table 1. Formulations of control (T1), and formulations with $20 \%$ (T2) and $30 \%$ (T3) reduced sodium.

\begin{tabular}{|c|c|c|c|}
\hline Raw materials/Ingredients & T1 $(\%)$ & $\mathrm{T} 2(\%)$ & $\mathrm{T} 3(\%)$ \\
\hline Lean pork retail $^{1}$ & 70.29 & 69.75 & 69.99 \\
\hline Fat pork retail ${ }^{2}$ & 15.00 & 15.00 & 15.00 \\
\hline Fat of pork leg and belly & 8.00 & 8.00 & 8.00 \\
\hline Water & 3.00 & 2.00 & 2.00 \\
\hline PuraQ ${ }^{\grave{A}}$ Arome NA4 (Corbion-Purac) & - & 2.00 & 2.00 \\
\hline Salt $-\mathrm{NaCl}(\text { Diana })^{3}$ & 1.50 & 1.04 & 0.80 \\
\hline Sausage condiment (Fuchs) ${ }^{4}$ & 0.50 & 0.50 & 0.50 \\
\hline Curing salt (Kerry) ${ }^{5}$ & 0.50 & 0.50 & 0.50 \\
\hline Sodium erythorbate (Kerry) & 0.20 & 0.20 & 0.20 \\
\hline Sausage emulsifier (Kerry) & 1.00 & 1.00 & 1.00 \\
\hline Cochineal carmine (Kerry) & 0.01 & 0.01 & 0.01 \\
\hline Total formulation & 100.00 & 100.00 & 100.00 \\
\hline Total $\mathrm{NaCl}$ (theoretical) & 2.33 & 1.87 & 1.63 \\
\hline
\end{tabular}

1: Average of $25 \%$ lipid; 2 : average of $50 \%$ lipid; 3: $99.2 \% \mathrm{NaCl} ; 4: 70 \% \mathrm{NaCl} ; 5: 97 \% \mathrm{NaCl}$ and $3 \%$ sodium nitrite; Total theoretical $\mathrm{NaCl}$ added to each formulation was based on the sum of $\mathrm{NaCl}$ present in the salt, condiment and curing salt.

The weight loss after thawing (WLT) was performed by weighing samples frozen at $-18^{\circ} \mathrm{C}$ (W1) and after $20 \mathrm{~h}$ of equilibration of temperature in the refrigerated chamber at $8^{\circ} \mathrm{C}(\mathrm{W} 2)$. The analysis was performed in triplicate, and the calculation was performed according to the equation: $\mathrm{WLT}=(\mathrm{W} 1-$ $\mathrm{W} 2$ ) / W1 * 100. Weight loss on cooking (WLC) was performed by weighing samples before (W3) and after cooking (W4) in a preheated electric oven at $250^{\circ} \mathrm{C}$ (model 10537-13368, Fisher, Brusque, $\mathrm{BR}$ ) for $75 \mathrm{~min}$, ensuring that the temperature at the geometric centre of the product reached at least $72^{\circ} \mathrm{C}$. The analysis was performed in triplicate, and the calculation was performed according to the equation: $\mathrm{WLC}=(\mathrm{W} 3-\mathrm{W} 4) / \mathrm{W} 3 * 100$. 
The moisture content, lipid, protein, calcium, chloride and $\mathrm{pH}$ were analysed according to the methodologies of Normative Instruction (NI) $n^{\circ}$ 20 of 06/21/1999 (BRASIL, 1999), and sodium (INSTITUTO ADOLFO LUTZ, 2005) was analysed by atomic emission spectroscopy using a flame photometer (FC-180 model, Celm, São Paulo, BR). Water activity (Aw) was determined using a water activity meter (model DCG-40530, Decagon, WA, USA). All the analyses were performed in triplicate.

The colour measurements were performed on the surface of thawed raw sausages and by reading at five different points per sample using a colorimeter (model CR400, Konica Minolta, NJ, USA) with an integrating sphere and $45^{\circ}$ viewing angle (lighting $\mathrm{d} / 45$ and illuminating $\mathrm{D})$. The values obtained were lightness $\left(\mathrm{L}^{*}\right)$, chroma $\left(\mathrm{C}^{*}\right)$, which refers to colour saturation, and hue $\left(\mathrm{h}^{\circ}\right)$.

The instrumental texture analysis was performed in a texturometer (model TA.XT/Plus/50, Stable Micro System, Godalming, UK) calibrated with a 5 $\mathrm{kg}$ load cell. The samples were cut into 12 cylinders of $20 \mathrm{~mm}$ in length and subjected to shear force determination (probe: HDP/WBV; test speed: 2.0 $\mathrm{mm} \mathrm{s}^{-1}$; penetration into the sample: $30 \mathrm{~mm}$; applied force: $5 \mathrm{~g}$ ). To evaluate the resistance to bite, 21 sausages were standardised with $10 \mathrm{~mm}$ long (probe: HDP/VB; test speed: $2.0 \mathrm{~mm} \mathrm{~s}^{-1}$; sample penetration: $25 \mathrm{~mm}$; applied force: $5 \mathrm{~g}$ ).

Microbiological analyses were performed in triplicate at the beginning of the period of validity for the count of mesophilic aerobic bacteria, moulds and yeasts, coagulase-positive Staphylococcus, and sulphite-reducing Clostridium following NI $\mathrm{n}^{\circ}$ 62 of 08/26/2003 (BRASIL, 2003) and the count of Coliforms $45^{\circ} \mathrm{C}$ was performed with Petrifilm methodology approved by AFNOR (3M-01/209/89/C). Salmonella spp. research test was performed according to the methodology approved by AFNOR (BIO-12/16-09/05).

Sensory analysis was performed according to the ethical precepts (CEP-UEL, CAAE
13086413.5.0000.5547, project 243.376) in individual booths with 60 untrained judges. The samples were thawed and baked (as indicated in WLT and WLC), cut into rings of approximately 1 $\mathrm{cm}$ thick, and served heated in white plastic plates coded with three random digits. Mineral water was served between samples to eliminate the aftertaste and for cleaning of the palate. The ordering of preference test was used, which asked the judges to evaluate the three samples and to indicate a preference in descending order (from most to least preferred). The test of hedonic scale ranged from "extremely disliked" (1) to "like extremely" (9) and was applied to evaluate the attributes of colour, appearance, texture, flavour and overall impression by a monadic evaluation of samples. The acceptability index (AI) was calculated according to the equation (TEIXEIRA et al., 1987): AI = average grade / highest score * 100. An experimental randomised block design considering the samples and the judges as a source of variation was used.

The results were analysed by ANOVA and Tukey test (Statistica 8.0, Statsoft Inc., Tulsa, OK, USA). The ordering of preference test was analysed according to a Christensen Table (DUTCOSKY, 2013), where to get a significant difference between samples, the sum of grades assigned for each sample should have a minimum difference of 22 when considering 60 assessments $(\mathrm{p} \leq 0.05)$.

\section{Results and Discussion}

\section{Physico-chemical quality}

Formulation $\mathrm{T} 1$ had the lowest WLT, while the largest WLT was observed for $\mathrm{T} 2(\mathrm{p} \leq 0.05)$. The WLC was statistically similar for the three formulations ( $\mathrm{p} \geq 0.05$; Table 2$)$. The ability to bind, immobilise and retain endogenous and exogenous water in the processed meat is assigned to myofibrillar proteins, which are influenced by the meat ingredients (STRASBURG et al., 2010). NaCl is an essential ingredient, which stands between the myofibrillar proteins while keeping the myofibrils 
spaced, allowing greater water retention (PEREDA et al., 2005). Due to the effect of $\mathrm{NaCl}$, higher water retention was expected in $\mathrm{T} 1$ formulation (without reduction of $\mathrm{NaCl}$ ).

Maia Junior (2013) produced fresh sausages with sheep meat with $31 \%$ lipid-content reduction and, at the same time, $25 \%$ and $50 \%$ sodium reduction by substituting $\mathrm{NaCl}$ for $\mathrm{KCl}$, compared with a formulation without reduction that contained $2.20 \%$ $\mathrm{NaCl}$. The control formulation WLC was $26.47 \%$, which was lower than the $33.64 \%$ and $30.68 \%$ reported for the formulations with $25 \%$ and $50 \%$ sodium reduction, respectively.

Table 2. Results of the physico-chemical analyses of the formulation control (T1), and formulations with 20\% (T2) and $30 \%$ (T3) reduced sodium.

\begin{tabular}{lcccc}
\hline Physico-chemical parameter & Legislation $^{1}$ & $\mathrm{~T} 1$ & $\mathrm{~T} 2$ & $\mathrm{~T} 3$ \\
\hline WLT (\%) & - & $0.3^{\mathrm{a}} \pm 0.1$ & $0.8^{\mathrm{b}} \pm 0.1$ & $0.6^{\mathrm{ab}} \pm 0.2$ \\
WLC (\%) & - & $39.3^{\mathrm{a}} \pm 2.4$ & $41.4^{\mathrm{a}} \pm 1.9$ & $43.4^{\mathrm{a}} \pm 2.3$ \\
Moisture (\%) & Max. 70\% & $62.5^{\mathrm{b}} \pm 0.8$ & $66.3^{\mathrm{a}} \pm 0.4$ & $67.5^{\mathrm{a}} \pm 0.4$ \\
Lipid (\%) & Max. 25\% & $19.6^{\mathrm{a}} \pm 1.0$ & $13.6^{\mathrm{b}} \pm 0.2$ & $12.2^{\mathrm{b}} \pm 0.6$ \\
Protein (\%) & Min. $12 \%$ & $13.6^{\mathrm{a}} \pm 0.4$ & $15.3^{\mathrm{b}} \pm 0.2$ & $16.3^{\mathrm{a}} \pm 0.2$ \\
Chloride (\%) & - & $2.3^{\mathrm{a}} \pm 0.1$ & $2.1^{\mathrm{ab}^{\mathrm{b}}} \pm 0.1$ & $1.9^{\mathrm{b}} \pm 0.2$ \\
Sodium (mg 100 g-1) & - & $926.7^{\mathrm{a}} \pm 22.0$ & $857.3^{\mathrm{ab}} \pm 44.5$ & $790.3^{\mathrm{b}} \pm 27.7$ \\
Aw & - & $0.967^{\mathrm{b}} \pm 0.004$ & $0.982^{\mathrm{a}} \pm 0.006$ & $0.970^{\mathrm{b}} \pm 0.003$ \\
Calcium (dry base) (\%) & Max. $0.1 \%$ & $0.05^{\mathrm{a}} \pm 0.01$ & $0.05^{\mathrm{a}} \pm 0.03$ & $0.03^{\mathrm{a}} \pm 0.01$ \\
pH & - & $5.88^{\mathrm{a}} \pm 0.02$ & $5.81^{\mathrm{b}} \pm 0.02$ & $5.82^{\mathrm{b}} \pm 0.02$ \\
$\mathrm{~L}^{*}$ & - & $61.0^{\mathrm{a}} \pm 2.2$ & $55.7^{\mathrm{b}} \pm 1.5$ & $49.8^{\mathrm{c}} \pm 2.3$ \\
$\mathrm{C}^{*}$ & - & $14.2^{\mathrm{a}} \pm 1.9$ & $15.4^{\mathrm{a}} \pm 2.5$ & $14.9^{\mathrm{a}} \pm 2.1$ \\
$\mathrm{~h}^{0}$ & - & $42.0^{\mathrm{a}} \pm 2.9$ & $36.2^{\mathrm{b}} \pm 3.2$ & $28.5^{\mathrm{c}} \pm 2.4$ \\
Resistance to bite (N) & - & $10.1^{\mathrm{a}} \pm 1.6$ & $11.8^{\mathrm{b}} \pm 2.0$ & $11.3^{\mathrm{ab}} \pm 1.9$ \\
Shear force (N) & - & $24.9^{\mathrm{a}} \pm 2.7$ & $26.0^{\mathrm{a}} \pm 3.6$ & $24.8^{\mathrm{a}} \pm 3.1$ \\
\hline
\end{tabular}

1: NI $n^{\circ} 4$ of 03/31/2000 (BRASIL, 2000); 2: weight loss after thawing; 3: weight loss on cooking; Mean \pm standard deviation ( $\mathrm{n}=3$; except for $L^{*}, C^{*}$ and $h^{0} n=5$; resistance to bite $n=21$; and shear force $n=12$ ). Means with different superscript letters on the same line have significant difference $(\mathrm{p} \leq 0.05)$.

The moisture contents of $\mathrm{T} 2$ and $\mathrm{T} 3$ were higher than that of $\mathrm{T} 1$, while the lipid contents of $\mathrm{T} 2$ and T3 were lower than that of T1 (Table 2). The protein content was higher in formulation T3, followed by $\mathrm{T} 2$ and $\mathrm{T} 1$ (Table 2). Variations in moisture, lipid and protein content are likely correlated with variations in the raw material.

In Toscana-type sausage samples, Paulino et al. (2006) reported a moisture content of 52.65\% for the control and $59.10 \%$ for a sample with $25 \%$ sodium and lipid reduction. For the same formulations, the lipid content was $28.43 \%$ and $19.08 \%$, while the protein content was $16.11 \%$ and $17.28 \%$, respectively. The moisture reported by these authors was lower than that obtained in the present work, while the lipid content and protein values were higher.

The chloride content was higher in formulation $\mathrm{T} 1$, followed by $\mathrm{T} 2$ and $\mathrm{T} 3$, but only the $\mathrm{T} 3$ content was statistically different from T1. A higher content of chloride was expected for $\mathrm{T} 1$, because $\mathrm{T} 2$ and $\mathrm{T} 3$ had a gradual reduction in $\mathrm{NaCl}$, and the sodium substitute employed did not have chloride in its composition. Similarly, Aaslyng et al. (2014) reported a significant decrease in chloride content of sausages with reduced $\mathrm{NaCl}$. Control formulation had $2.19 \%$ chloride, while formulations containing $0.5 \%$ and $1 \%$ less $\mathrm{NaCl}$ had $1.74 \%$ and $1.23 \%$ chloride, respectively. 
The sodium content of $\mathrm{T} 1$ and $\mathrm{T} 2$ was similar

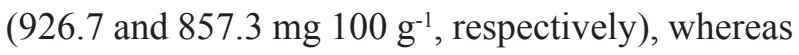
the sodium content of T3 was statistically lower than T1 (790.3 mg $\left.100 \mathrm{~g}^{-1}\right)$. Theoretically, the sodium level was reduced by $20 \%$ (T2) and $30 \%$ (T3), but in fact, there was a reduction of $7.5 \%$ (T2) and $14.7 \%$ (T3) compared with T1 considering the results of analyses for sodium. Triki et al. (2013) reported 38\% sodium reduction in fresh Merguez sausages (a kind of sausage of North Africa) when comparing a control formulation $(630.7 \mathrm{mg} 100$ $\mathrm{g}^{-1}$ ) with a formulation whose $\mathrm{NaCl}$ was partially substituted by a mixture of $\mathrm{KCl}$, calcium chloride and magnesium chloride (391.0 mg $\left.100 \mathrm{~g}^{-1}\right)$. The sodium reduction obtained by these authors was higher than that reported in the present work, but the type of sausage and the sodium substitute employed were different.

Aw was higher in formulation T2, which differed from T1 and T3. Many sodium substitutes can give a salty taste, though not all act by reducing Aw as $\mathrm{NaCl}$ does. The PuraQ Arome NA4 is supposed to give a salty taste and to ensure the reduction of $\mathrm{Aw}$ (CORBION-PURAC, 2013); however, T2 had a higher Aw than T1. Silva et al. (2014) reported lower Aw values in Toscana sausages ( 0.952 to 0.968 ) than those determined in this work. Differences in Aw can be directly linked to food product composition.

The calcium content was similar for all formulations (Table 2), and all met the Brazialian legislation (BRASIL, 2000). In Toscana sausage manufacture, mechanically deboned meat is prohibited (BRASIL, 2000), and so it is important to analyse calcium content to identify potential fraud, because according to Souza et al. (2003), how much mechanically deboned meat is added higher is the calcium content of meat products.

The $\mathrm{pH}$ of the formulation T1 (5.9) was higher than that of T2 and T3 (both 5.8). Results of $\mathrm{pH}$ that were slightly higher than determined in this work were reported by Silva et al. (2014) in Toscana sausage samples, ranging from 6.07 to 6.10 on the first day after manufacture.
The lightness $\left(\mathrm{L}^{*}\right)$ was higher in formulation T1, followed by T2 and T3. How lower L* is, more dark the samples are, than T3 and T2 had lower L*, which corresponds to an intense red colour. Bradley et al. (2011) reported lower L* values (47.6 to 50.4) than those obtained in the present work, indicating fresh pork sausage samples produced by them had a more intense red colour.

The chroma $\left(\mathrm{C}^{*}\right)$ is the colour saturation, and was similar between samples. The hue $\left(h^{0}\right)$ was lower in the formulation T3, followed by $\mathrm{T} 2$ and T1. At angles of $0^{\circ}$ and $90^{\circ}$, the predominant colour is red and yellow, because $\mathrm{h}^{0}$ reported for T3 is the closest to $0^{\circ}$ there was a greater amount of red in this sample, followed by T2 and T1. Therefore, sample T3 had a more intense red colour, while T1 had a less intense red colour. As mentioned above, the $\mathrm{pH}$ of $\mathrm{T} 2$ and $\mathrm{T} 3$ was lower than that of $\mathrm{T} 1$ and, according to Milani et al. (2003), the $\mathrm{pH}$ of the sausage exerts direct influence on their conservation and colour.

The instrumental evaluation of texture showed that $\mathrm{T} 2 \mathrm{had}$ a greater resistance to bite than $\mathrm{T} 1$, but not T3. However, the shear force was similar between formulations (Table 2). Similarly, Araújo (2012) reported no significant difference $(p>0.05)$ in shear force between control fresh sausage samples of chicken and samples with different levels of substitution of $\mathrm{NaCl}$ by $\mathrm{KCl}$ and a mix of basil, oregano and rosemary.

\section{Microbiological quality}

All formulations analysed met the microbiological criteria of Brazilian legislation (Table 3) (BRASIL, 2001). Salmonella spp. was not detected on the formulations. The count of coagulase-positive Staphylococcus was $<10^{2} \mathrm{CFU} \mathrm{g}^{-1}$, while the count of sulphite-reducing Clostridium and Coliforms at $45^{\circ} \mathrm{C}$ were $<10^{1} \mathrm{CFU} \mathrm{g}^{-1}$ for $\mathrm{T} 1, \mathrm{~T} 2$ and $\mathrm{T} 3$. Similarly, Bernardi and Roman (2011a) reported no Salmonella, and counts of Staphylococcus aureus and Coliforms at $45^{\circ} \mathrm{C}$ were $<1.0 \times 10^{1} \mathrm{CFU}$ 
$\mathrm{g}^{-1}$ in Toscana sausages without $\mathrm{NaCl}$, and with $0.67 \% \mathrm{NaCl}$. Maia Junior et al. (2013) produced fresh pork sausages with addition of $1.8 \% \mathrm{NaCl}$ (control) and with $1.8 \%$ of light salt $(\mathrm{NaCl} / \mathrm{KCl})$. They found no presence of Salmonella spp. and no growth of Staphylococcus aureus, sulphite-reducing Clostridium and Coliforms at $45^{\circ} \mathrm{C}$ in the samples.

The count of mesophilic aerobic bacteria was $1.2 \times 10^{3} \mathrm{CFU} \mathrm{g}^{-1}$ in sample $\mathrm{T} 1$, followed by $3.0 \times 10^{3}$ $\mathrm{CFU} \mathrm{g}^{-1}$ in T2 and 5.0x10 $0^{3} \mathrm{CFU} \mathrm{g}^{-1}$ in T3. Similarly,

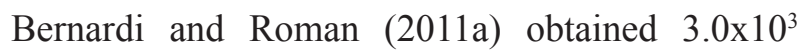
CFU $\mathrm{g}^{-1}$ of mesophilic aerobic bacteria in Toscana sausages without added $\mathrm{NaCl}$ and $2.4 \times 10^{3} \mathrm{CFU} \mathrm{g}^{-1}$ in the sausages with $0.67 \% \mathrm{NaCl}$.

The count of moulds and yeasts was $<10^{2}$ CFU g ${ }^{-1}$ for T1, T2 and T3. Aaslyng et al. (2014) evaluated the effect of $\mathrm{NaCl}$ reduction in meat products stored at $5^{\circ} \mathrm{C}$. They reported counts of mould and yeasts of $<10^{1} \mathrm{CFU} \mathrm{g}^{-1}$ for samples of sausage, ham and salami after 29, 28 and 60 days of storage, respectively. These results suggest there was no growth of this group of microorganisms due to the $\mathrm{NaCl}$ reduction.

Table 3. Results of microbiological analyses of control formulation (T1), and formulations with $20 \%$ (T2) and $30 \%$ (T3) reduced sodium.

\begin{tabular}{lcccc}
\hline Microbiological parameters & Legislation $^{1}$ & $\mathrm{~T} 1$ & $\mathrm{~T} 2$ & $\mathrm{~T} 3$ \\
\hline Salmonella spp. (in 25 g) & Absence & Absence & Absence & Absence \\
Coagulase-positive Staphylococcus $\left.(\mathrm{CFU} \mathrm{g})^{-1}\right)^{2}$ & $5 \times 10^{3}$ & $<10^{2}$ & $<10^{2}$ & $<10^{2}$ \\
Sulphite-reducing Clostridium $\left(\mathrm{CFU} \mathrm{g}^{-1}\right)$ & $3 \times 10^{3}$ & $<10^{1}$ & $<10^{1}$ & $<10^{1}$ \\
Coliform at 45 $\mathrm{C}\left(\mathrm{CFU} \mathrm{g}{ }^{-1}\right)$ & $5 \times 10^{3}$ & $<10^{1}$ & $<10^{1}$ & $<10^{1}$ \\
Mesophilic aerobic bacteria $\left(\mathrm{CFU} \mathrm{g}{ }^{-1}\right)$ & - & $1.2 \times 10^{3}$ & $3.0 \times 10^{3}$ & $5.0 \times 10^{3}$ \\
Moulds and yeasts $\left(\mathrm{UFC} \mathrm{g}^{-1}\right)$ & - & $<10^{2}$ & $<10^{2}$ & $<10^{2}$ \\
\hline
\end{tabular}

1: $\mathrm{RDC} \mathrm{n}^{\circ} 12$ 01/02/2001 (BRASIL, 2001); 2: colony-forming unit per gram of sample. Results expressed as mean ( $\mathrm{n}=3$ ).

\section{Sensory quality}

The ordering of preference test showed that $\mathrm{T} 2$ was the most preferred sample, and significantly differed from $\mathrm{T} 1$ and $\mathrm{T} 3(\mathrm{p} \leq 0.05)$. In contrast, the formulations did not differ $(p \leq 0.05)$ when evaluated by hedonic scale for the attributes of roast colour, aroma, texture, flavour and overall impression (Table 4). The acceptability index was greater than $74.6 \%$ for all attributes evaluated in $\mathrm{T} 1, \mathrm{~T} 2$ and $\mathrm{T} 3$, indicating that all samples were sensorially acceptable, because the minimum limit for $\mathrm{AI}$ is $70 \%$ for sensory acceptance (TEIXEIRA et al., 1987). As the sample T2 had the highest average values in the sensory acceptance test, T2 also obtained the highest AI.

Bernardi and Roman (2011b) obtained AI values of $81 \%, 82 \%, 83 \%$ and $85 \%$ for flavour, aroma, colour and texture of Toscana sausages with $0.67 \%$ $\mathrm{NaCl}$ added. These AI values were similar to those obtained for the $\mathrm{T} 2$ formulation (with $1.87 \% \mathrm{NaCl}$ added), i.e. $82.6 \%, 80.2 \%, 78.2 \%$ and $83.9 \%$ for flavour, aroma, colour and texture. 
Table 4. Results of sensory analyses of control formulation (T1), and formulations with $20 \%$ (T2) and $30 \%$ (T3) reduced sodium.

\begin{tabular}{lccc}
\hline Sensory parameters & $\mathrm{T} 1$ & $\mathrm{~T} 2$ & $\mathrm{~T} 3$ \\
\hline Sum & \multicolumn{3}{c}{ Ordering of preference test } \\
\hline & $110^{\mathrm{b}}$ & $139^{\mathrm{a}}$ & $111^{\mathrm{b}}$ \\
Roasted colour & & Hedonic scale \\
Aroma & $6.7^{\mathrm{a}} \pm 1.5$ & $7.0^{\mathrm{a}} \pm 1.4$ & $7.0^{\mathrm{a}} \pm 1.3$ \\
Texture & $6.9^{\mathrm{a}} \pm 1.7$ & $7.2^{\mathrm{a}} \pm 1.3$ & $7.0^{\mathrm{a}} \pm 1.5$ \\
Flavour & $7.3^{\mathrm{a}} \pm 1.5$ & $7.6^{\mathrm{a}} \pm 1.0$ & $7.1^{\mathrm{a}} \pm 1.6$ \\
Overall impression & $7.1^{\mathrm{a}} \pm 1.5$ & $7.4^{\mathrm{a}} \pm 1.2$ & $7.1^{\mathrm{a}} \pm 1.2$ \\
& $7.2^{\mathrm{a}} \pm 1.4$ & $7.4^{\mathrm{a}} \pm 1.3$ & $7.2^{\mathrm{a}} \pm 1.3$ \\
Roasted colour & & Acceptability index \\
Aroma & $74.6 \%$ & $78.2 \%$ & $77.6 \%$ \\
Texture & $76.1 \%$ & $80.2 \%$ & $77.6 \%$ \\
Flavour & $81.3 \%$ & $83.9 \%$ & $78.7 \%$ \\
Overall impression & $78.7 \%$ & $82.6 \%$ & $78.3 \%$ \\
\hline
\end{tabular}

Ordering of preference test: sums with different letters superscript in the same line have a statistical difference ( $\mathrm{p} \leq 0.05)$; Hedonic scale: mean of sensory values \pm standard deviation $(n=60)$; means with different superscript letters on the same line have a significant difference $(\mathrm{p} \leq 0.05)$.

\section{Conclusions}

The sodium content was significantly lower $(\mathrm{p} \leq 0.05)$ in sausages with reduced $\mathrm{NaCl}$. However, the formulations with a theoretical $20 \%$ and $30 \%$ sodium reduction, in fact, led to only a $7.5 \%$ and $14.7 \%$ reduction compared with the control. All formulations met the physico-chemical and microbiological criteria of Brazilian legislation. Sensory acceptance was obtained for all samples, but the sample with a theoretical $20 \%$ reduction in sodium was the most preferred. Therefore, the PuraQ Arome NA4, when applied at a concentration of $2 \%$ and combined with a $20 \%$ reduction in the $\mathrm{NaCl}$ added, allowed to obtain a product with reduced sodium content that met the legal criteria and was sensorially accepted by consumers.

\section{References}

AASLYNG, M. D.; VESTERGAARD, C.; KOCH, A. G. The effect of salt reduction on sensory quality and microbial growth in hotdog sausages, bacon, ham and salami. Meat Science, Amsterdam, v. 96, n. 1, p. 47-55, 2014.
ASSOCIAÇÃO BRASILEIRA DA INDÚSTRIA PRODUTORA E EXPORTADORA DE CARNE SUÍNA - ABIPECS. Carne Suína Brasileira. São Paulo: Abipecs, 2012. Disponível em: <http://file. aviculturaindustrial.com.br/Material/Relatorio/2012/ abipecs_relatorio_2011_pt.pdf>. Acesso em: 15 fev. 2016.

ARAÚJO, I. B. S. Otimização do uso de sal de ervas e cloreto de potássio na substituição parcial do cloreto de sódio em corte e em linguiça de frango. 2012. Dissertação (Mestrado em Tecnologia Agroalimentar) - Centro de Ciências Humanas, Sociais e Agrárias, Universidade Federal da Paraíba, Bananeiras.

BERNARDI, D. M.; ROMAN, J. A. Caracterização sensorial de linguiça Toscana com baixo teor de sódio e análise do consumo de carne suína e derivados na região Oeste do Paraná. Boletim do Centro de Pesquisa e Processamento de Alimentos, Curitiba, v. 29, n. 1, p. 33-42, jan./jun. $2011 b$.

Linguiça toscana com redução no teor de sódio: caracterização microbiológica, físico-química e nutricional. Nutrição Brasil, São Paulo, v. 10, p. 11-15, 2011a.

BRADLEY, E. M.; WILLIAMS , J. B.; SCHILLING, M. W.; COGGINS, P. C.; CRIST, C.; YODER, S.; CAMPANO, S. G. Effects of sodium lactate and acetic acid derivatives on the quality and sensory characteristics of hot-boned pork sausage patties. Meat Science, Amsterdam, v. 88, n. 1, p. 145-150, 2011. 
BRASIL. Ministério da Agricultura, Pecuária e Abastecimento. Instrução Normativa $\mathrm{n}^{\mathrm{o}} 20$, de 21/08/1999. Oficializa os Métodos Analíticos FísicoQuímicos, para Controle de Produtos Cárneos e seus Ingredientes - Sal e Salmoura. Diário Oficial [da] União, Brasília, 27 ago. 1999.

Ministério da Agricultura, Pecuária e Abastecimento. Instrução Normativa no 4 de 31/03/2000. Aprova os Regulamentos Técnicos de Identidade e Qualidade de Carne Mecanicamente Separada, de Mortadela, de Linguiça e de Salsicha. Diário Oficial [da] União, Brasília, 05 abr. 2000. Seção 1, p. 6-10.

Ministério da Agricultura, Pecuária e Abastecimento. Instrução Normativa n ${ }^{\circ} 62$ de 26/08/2003. Oficializa os Métodos Analíticos Oficiais para Análises Microbiológicas para Controle de Produtos de Origem Animal e Água. Diário Oficial [da] União, Brasília, 18 set. 2003. Seção 1, p. 14-51.

- Ministério da Saúde, Agência Nacional de Vigilância Sanitária. Resolução RDC $n^{\circ} 12$, de 02/01/2001. Aprova o Regulamento técnico sobre padrões microbiológicos para alimentos. Diário Oficial [da] União, Brasília, 10 jan. 2001. Seção 1, p. 45-53.

CARRARO, C. I.; MACHADO, R.; ESPINDOLA, V.; CAMPAGNOL, P. C. B.; POLLONIO, M. A. R. The effect of sodium reduction and the use of herbs and spices on the quality and safety of bologna sausage. Ciência e Tecnologia de Alimentos, Campinas, v. 32, n. 2, p. 289295, abr./jun. 2012.

CORBION-PURAC. PuraQ Arome NA4 natural flavoring for reduced-sodium meat products. Amterdam: Corbion, 2013. 2 p. Available at: <http://www. corbion. com/media/166736/puraqaromena4-useng-1013.pdf $>$. Accessed at: 12 set. 2014.

DESMOND, E. Reducing salt: a challenge for the meat industry. Meat Science, Amsterdam, v. 74, n. 1, p. 188196, 2006.

DUTCOSKY, S. D. Análise sensorial de alimentos. 4. ed. Curitiba: Champagnat, 2013. 531 p.

GOU, P.; GUERRERO, L.; GELABERT, J.; ARNAU, J. Potassium chloride, potassium lactate and glycine as sodium chloride substitutes in fermented sausages and in dry-cured pork loin. Meat Science, Amsterdam, v. 42, n. 1, p. 37-48, 1996.

HE, F. J.; MACGREGOR, G. A. Reducing population salt intake worldwide: from evidence to implementation. Progress in Cardiovascular Diseases, New York, v. 52, n. 5, p. 363-382, 2010.
HENDERSON, L.; IRVING, K.; GREGORY, J. The national diet \& nutrition survey: adults aged 19 to 64 years: vitamin and mineral intake and urinary analytes. Londres: TSO, 2003. v. 2, 160 p.

INSTITUTO ADOLFO LUTZ - IAL. Métodos físicoquímicos para análises de alimentos. 4. ed. São Paulo: IAL, 2005. 1020 p.

JIMÉNEZ-COLMENERO, F.; CARBALLO, J.; COFRADES, S. Healthier meat and meat products: their role as functional foods. Meat Science, Amsterdam, v. 59, n. 1, p. 5-13, 2001.

MAIA JUNIOR, J. A. Características físico-químicas de linguiça frescal ovina com baixos teores de gordura e cloreto de sódio. 2013. Dissertação (Mestrado em Ciência Animal) - Centro de Ciências e Tecnologias Agropecuárias. Universidade Estadual do Norte Fluminense Darcy Ribeiro, Campos dos Goytacazes.

MAIA JUNIOR, J. A.; HENRY, F. C.; VALLE, F. R. F. A.; MARTINS, M. L. L.; QUIRINO, C. R.; COSTA, R. S. Reducing fat and sodium content in pork sausage. African Journal of Biotechnology, Nairobi, v. 12, n. 24, p. 3847-3853, 2013.

MA, F.; CONGGUI, C.; ZHENG, L.; ZHOU, C.; CAI, K.; HAN, Z. Effect of high pressure processing on the gel properties of salt-soluble meat protein containing $\mathrm{CaCl} 2$ and k-carrageenan. Meat Science, Amsterdam, v. 95, n. 1, p. 22-26, 2013.

MILANI, L. I. G.; FRIES, L. L. M.; PAZ, P. B.; BELLE, M.; TERRA, N. N. Bioproteção de linguiça de frango. Ciência e Tecnologia de Alimentos, Campinas, v. 23, n. 2, p. 161-166, 2003.

PAULINO, F. O.; SILVA, T. J. P.; FRANCO, R. M.; FREITAS, M. Q.; FERNANDES, M. L. Redução parcial dos teores de gordura e sal em embutido cárneo suíno com utilização de goma carragena e cloreto de potássio. Revista Brasileira de Ciência Veterinária, Niterói, v. 13, n. 2, p. 121-124, 2006.

PEREDA, J. A. O.; RODRÍGUES, M. I. C.; ÁLVAREZ, L. F.; SANZ, M. L. G.; MINGUILLÓN, G. D. G. F.; PERALES, L. H.; CORTECERO, M. D. S. Tecnologia de alimentos: alimentos de origem animal. São Paulo: Artmed, 2005. v. 2, 279 p.

RUUSUNEN, M.; PUOLANNE, E. Reducing sodium intake from meat products. Meat Science, Amsterdam, v. 70, n. 3, p. 531-541, 2005. 
SANTOS, B. A.; CAMPAGNOL, P. C. B.; TRIKI, M.; HERRERO, A. M.; JIMÉNEZCAVAlCANTI, R. N.; PACHECO, M. T. B.; NETTO, COLMENERO, F.; RUIZ-CAPILlAS, C. Storage F. M.; MOTTA, E. M. P.; CELEGUINI, R. M. S.; stability of low-fat sodium reduced fresh merguez WAGNER, R.; POLLONIO, M. A. R. Impact of sodium chloride replacement by salt substitutes on the proteolysis and rheological properties of dry fermented sausages. Journal of Food Engineering, Londres, v. 151, p. 16-24, 2015.

SARNO, F.; CLARO, R. M.; LEVY, R. B.; BANDONI, D. H.; MONTEIRO, C. A. Estimated sodium intake for the Brazilian population, 2008-2009. Revista de Saúde Pública, São Paulo, v. 47, n. 3, p. 1-7, 2013.

SILVA, R. X. A.; JOSÉ, K. F. C.; FRANCO, R. M.; SILVA, T. J. P. Lactato de sódio, nisina e sua combinação na validade comercial da linguiça Toscana embalada a vácuo e estocada a $4^{\circ} \mathrm{C}$. Revista Ciência Rural, Santa Maria, v. 44, n. 4, p. 746-751, 2014.

SOUZA, E. A.; TEIXEIRA, L. C. V.; MELLO, M. R. P. D.; TORRES, E. A. F. D.; MOITA NETO, J. M. Aplicação de redes neurais para avaliação do teor de carne mecanicamente separada em salsicha de frango. Ciência e Tecnologia de Alimentos, Campinas, v. 23, n. 3, p. 307-311, set./dez. 2003.

STRASBURG, G.; XIONG, Y. L.; CHIANG W. Fisiologia e química dos tecidos musculares comestíveis. In: DAMODARAN S.; PARKIN, K. L.; FENNEMA, O. R. Química de alimentos de fennema. Porto Alegre: Artmed, 2010. p. 719-757.

TEIXEIRA, E.; MEINERT, E. M.; BARBETTA, P. A. Análise sensorial de alimentos. Florianópolis: UFSC, 1987. $180 \mathrm{p}$. sausage prepared with olive oil in konjac gel matrix. Meat Science, Amsterdam, v. 94, n. 4, p. 438-446, 2013.

TSENG, T.; LIU, D.; CHEN, M. Evaluation of transglutaminase on the quality of low-salt chichen meatballs. Meat Science, Amsterdam, v. 55, n. 4, p. 427-431, 2000.

WENJIAO, F.; YONGKUI, Z.; YUNCHUAN, C.; JUNXIU, S.; YUWEN, Y. TBARS predictive models of pork sausages stored at different temperatures. Meat Science, Amsterdam, v. 96, n. 1, p. 1-4, 2014.

WORLD HEALTH ORGANIZATION - WHO. Guideline: sodium intake for adults and children. Geneva: World Health Organization, WHO, 2012. 46 p.

WILSON, R.; KOMITOPOULOU, E.; INCLES, M. Evaluation of technological approaches to salt reduction. Surrey: Leatherhead Food Research, 2012. 222 p.

WIRTH, F. Reducing the fat and sodium content of meat products. What possibilities are there? Fleischwirtschaft, Frankfurt, v. 71, n. 3, p. 294-297, 1991.

ZHAO, D.; QI, Y.; ZHENG, Z.; WANG, Y.; ZHANG, X. Y.; LI, H. J.; LIU, H. H.; ZHANG, X. T.; DU, J.; LIU, J. Dietary factors associated with hypertension. Nature Reviews Cardiology, London, v. 8, n. 8, p. 456-465, 2011. 